CELINA CZECH-WŁODARCZYK

\title{
POTENCJAŁ SPOŁECZNY I PEDAGOGICZNY KONCEPCJI SOCIAL RESILIENCE W ERZE NEOLIBERALNEJ
}

\begin{abstract}
Streszczenie: W artykule pragnę zaprezentować potencjał społeczny i pedagogiczny koncepcji social resilience, która może być skutecznym sposobem utrzymania swojego dobrostanu przez jednostki i społeczności, zwłaszcza w obliczu zagrożeń spowodowanych oddziaływaniem ideologii neoliberalnej. W sposób kompleksowy zaprezentuję definicje pojęć stosowanych w artykule, takich jak: resilience, social resilience, ideologia neoliberalna. Postaram się przytoczyć przykłady wykorzystania potencjału społecznego koncepcji social resilience, które aktualnie z powodzeniem funkcjonują we współczesnych państwach demokratycznych. Zaprezentuję także przykłady dotychczasowego zastosowania koncepcji resilience na gruncie polskiej psychologii i pedagogiki oraz wskażę możliwości poszerzenia tej koncepcji o czynnik społeczny (social) i wykorzystania jej potencjału pedagogicznego na gruncie edukacji.
\end{abstract}

Słowa kluczowe: resilience, social resilience, neoliberalizm.

Inspiracją do podjęcia tematu zamieszczonego w tytule artykułu była książka Petera A. Halla i Michèle Lamont Social Resilience in the Neoliberal Era. Książka jest efektem 10-letniej współpracy grona znanych badaczy z CIFAR (Canadian Institute for Advanced Research), którzy w swojej publikacji prezentują pogłębioną analizę instytucjonalną i kulturową skutków wpływu neoliberalizmu na życie współczesnych społeczeństw demokratycznych, a zwłaszcza małych społeczności lokalnych. Neoliberalizm jest postrzegany przez autorów książki jako „synkretyczne zjawisko społeczne”, które zawiera w sobie różnorodne znaczenia i praktyki społeczne. Autorzy książki dogłębnie analizująźródła resilience, która koncentruje się na poszukiwaniu możliwości prowadzenia owocnego i aktywnego życia przez jednostki. Z kolei koncepcja social resilience nie oznacza, zdaniem autorów, że społeczeństwa stawiające czoła przeciwnościom pokonują je, nie doznając zmian lub odczuwając je w minimalnym wymiarze, wręcz przeciwnie, social resilience pozwala jednostkom żyjącym w społecznościach krajów rozwiniętych i rozwijających się 
na życie w dobrostanie psychofizycznym i materialnym pomimo wyzwań, jakie stawia przed nimi dominujący współcześnie paradygmat rynkowy.

\section{Analiza znaczeń oraz kontekstów użycia social resilience}

Koncepcja social resilience wywiedziona jest z terminu resilience, którego zastosowanie, jak twierdzi Smulczyk, powoduje, że „Od wielu lat wśród badaczy toczy się dyskusja dotycząca problemów definicyjnych, trudności związanych z operacjonalizacją i pomiarem resilience" (Smulczyk 2016b, s. 167). Termin resilience obecny jest w specjalistycznej literaturze poświęconej ekologii, psychologii rozwojowej oraz psychologii klinicznej, zwłaszcza w publikacjach na temat reakcji środowiska i ludzi na katastrofy naturalne, konflikty zbrojne i zmiany klimatyczne (publikacje Simon Cottle lub Ann S. Masten i Angeli J. Narayan).

Wioletta Junik, autorka pierwszej polskiej zwartej publikacji poświęconej temu terminowi, postuluje, aby w polskim piśmiennictwie posługiwać się oryginalnym angielskim terminem resilience lub jego spolszczoną wersją - rezyliencja. Junik w swojej publikacji proponuje, aby ujmować resilience w kategoriach dynamicznego procesu, który umożliwia jednostce pokonanie przeciwności losu, a w przypadku social resilience podejmowanie kolektywnych działań w obliczu zagrożenia ideologicznego (Junik 2011). W niniejszym artykule pozostanę przy używaniu oryginalnego, angielskiego terminu.

Termin resilience według Cambridge Dictionary oznacza możliwość powrotu do poprzedniego dobrego samopoczucia (dobrostanu) po doświadczanym kryzysie, problemach. K. Gąsior wskazuje, powołując się na publikacje innych polskich badaczy, że termin ten zapożyczony został z dziedziny fizyki, gdzie oznacza wysoką elastyczność lub sprężystość materiałów odpornych na odkształcenia. Natomiast w naukach społecznych odnosi się do dobrego funkcjonowania jednostki lub grup społecznych w niekorzystnych warunkach. Resilience oznacza procesy i mechanizmy, które sprzyjają adaptacyjnemu i dobremu funkcjonowaniu jednostki, pomimo doświadczanych w przeszłości lub obecnie przeciwności losu i traumatycznych zdarzeń, choć zdaniem autora, „Nie oznacza więc tylko zdolności do radzenia sobie ze stresem. Nie jest też wyłącznie dyspozycją osobowościową, ale procesem, który w obliczu traumy i różnych czynników ryzyka pozwala jednostce zachować lub powrócić do zdrowego i adaptacyjnego funkcjonowania. Co więcej, resilience jako proces odniesiona została nie tylko do funkcjonowania jednostki, ale również grup i środowiska lokalnego" (Gąsior 2014, s. 80-81).

Na gruncie nauk o ekologii początkowo termin resilience stosowano do opisywania pewnych właściwości, które pozwalają systemowi na powrót do poprzedniego stanu po doświadczeniu szoku, który zagrażał jego dalszemu funkcjonowaniu, ale $\mathrm{w}$ ostatnich publikacjach ekolodzy rozpatrują resilience w kategoriach dynamicznego procesu, z naciskiem na jej adaptacyjną i transformacyjną funkcję dla całego systemu ekologicznego (np. Folke 2006). 
Na gruncie psychologii rozwojowej termin resilience został bardzo dobrze opisany w literaturze światowej, na co w swoich w pracach wskazują K. Ostaszewski i A. Borucka (2008) oraz W. Junik (2011). W szerokim ujęciu termin ten jest opisywany jako dynamiczny proces odzwierciedlający względnie dobre przystosowanie się jednostki, mimo doświadczanych przez nią zagrożeń lub traumatycznych przeżyć. Jak wskazują autorzy, „Resilience bywa także rozumiana jako proces rozwojowy, za pomocą którego dzieci nabywają umiejętności korzystania $\mathrm{z}$ wewnętrznych i zewnętrznych zasobów po to, by osiągnąć dobre przystosowanie (pozytywną adaptację) pomimo przeszłych lub obecnie występujących przeciwności losu” (Borucka, Ostaszewski 2008, s. 588).

Na gruncie psychologii klinicznej, zwłaszcza w obszarze poświęconym reakcji ludzi i społeczności na katastrofy naturalne, takie jak: trzęsienia ziemi, huragany, powodzie, pożary, a także konflikty zbrojne, ludobójstwo, terroryzm oraz zmiany klimatyczne, wskazuje się na to, że koncepcja resilience jest postrzegana jako „zdolność dynamicznego systemu do stawienia czoła lub przezwyciężenia znaczących zagrożeń, które zagrażają jego stabilności, zdolności do życia lub rozwoju. Resilience jest koncepcją dynamiczną, która może być zastosowana do badania [...] całej osoby jako zwartego systemu, systemu rodzinnego, systemu społecznościowego lub komunikacyjnego oraz ekosystemu" (Masten, Narayan 2012, s. 228).

Te trzy wyżej opisane sposoby definiowania terminu resilience mają swoje odzwierciedlenie w koncepcji social resilience, którą Hall i Lamont nierozerwalnie wiążą z terminem szeroko definiowanego dobrostanu (well-being) i jego zapewnieniu przez ludzi, mniej lub bardziej ze sobą związanych, w ramach organizacji, klasy społecznej, grupy rasowej, społeczności czy państwa. Stąd social resilence oznacza efekt, jaki osiągają członkowie grupy w zapewnieniu własnego dobrostanu w obliczu zagrożenia.

Dla jasności mojego wywodu jest konieczne wyjaśnienie, co autorzy książki rozumieją pod pojęciem well-being. Według Charlesa Taylora, na którego definicję powołują się autorzy książki, well-being definiowane szeroko, uwzględnia zdrowie fizyczne i psychiczne, zabezpieczenie materialne, poczucie godności i przynależności, które wynika z bycia rozpoznawalnym jako członek społeczności (Hall, Lamont 2013, za: Taylor 1994). Na tym szerokim ujęciu Hall i Lamont opierają swoją definicję well-being, choć celowo pomijają tworzenie dokładnej hierarchii potrzeb czy samoaktualizacji, jako celu osiąganego przez jednostki, ponieważ jak pokazują współczesne badania, wartości przypisane do tych celów różnią się pomiędzy populacjami i zależą od kontekstu, w jakim je rozpatrujemy. Autorzy postrzegają social resilience jako „dynamiczny proces, polegający nie na powrocie do poprzedniego stanu, ale pewnego rodzaju osiągnięcie polegające na zapewnieniu dobrostanu, nawet jeśli wymaga to modyfikacji zachowania lub modyfikacji społecznej ramy, która nadaje strukturę i przypisuje znaczenie konkretnemu zachowaniu" (Hall, Lamont 2013, s. 13). Podstawowym założeniem w ramach social resilience jest „zdolność jednostek i grup do zabezpieczenia pożądanego efektu 
(materialnego, symbolicznego, emocjonalnego) w obliczu nowych okoliczności, i jeśli to wymagane, także z koniecznością nadania nowego sensu poszczególnym wartościom" (Hall, Lamont 2013, s. 13).

W swojej książce Hall i Lamont koncepcję social resilience zestawiają z neoliberalizmem, który jest ideologią swoim zasięgiem obejmującą współcześnie niemal cały świat, a której oddziaływanie ma negatywne konsekwencje w sferze społecznej, ekonomicznej i politycznej życia obywateli i społeczeństw. Autorzy definiują neoliberalizm podobnie, jak w swoich publikacjach czyni to Harvey, „jako szeroko rozpowszechnione i dojmujące zjawisko, które wpływa na kształt stosunków społecznych, budując je na zaciętej rywalizacji rynkowej, minimalizując rolę państwa, a maksymalizując działania przedsiębiorcze podejmowane przez same jednostki" (Hall, Lamont 2013, s. 3).

\section{Charakterystyka cech i społecznych konsekwencji ideologii neoliberalnej}

Rozwijając myśl autorów, należy podkreślić, że neoliberalizm to ogólna nazwa zespołu koncepcji i poglądów ekonomicznych, społecznych, politycznych i etyczno-moralnych nawiązujących bezpośrednio do założeń ideologii „klasycznego” liberalizmu ekonomicznego i politycznego, zwłaszcza w wersji sformułowanej przez przedstawicieli anglo-szkockiego oświecenia. W sposób dosyć zwięzły pojęcie neoliberalizmu przedstawia Subir Sinha, który pisze, że: „Neoliberalizm - nowa moralność ostatnich dwóch dekad - był konstruowany jako projekt, który miał zaradzić «kryzysowi normalności» liberalizmu korporacyjnego, wywołanemu bojowymi wystąpieniami świata pracy, nowymi konfliktami społecznymi, następstwami wojny w Wietnamie oraz ogólnym wyczerpaniem się modelu. Polityka neoliberalna połączyła wiele różnych elementów: indywidualizm, wolność wyboru, społeczeństwo rynkowe, leseferyzm, minimalizację ingerencji rządu w gospodarkę, silną władzę w sferach pozagospodarczych, społeczny autorytaryzm, dyscyplinę, hierarchię i podporządkowanie, a także kult narodu. Taka kombinacja stanowi «politykę wsparcia» dla obowiązujących programów wdrażanych w krajach poddawanych neoliberalnym reformom" (Sinha 2009, s. 261).

Według ideologii neoliberalnej głównym zadaniem państwa w sferze gospodarki i spraw społecznych jest zapewnienie „ram prawnych” do funkcjonowania mechanizmów rynkowych w warunkach wolnej konkurencji. Dotyczy to zwłaszcza prawa własności, umów, związków, stowarzyszeń i osób prawnych. Państwo ma również prowadzić aktywną politykę antyinflacyjną. Ingerencja państwa ogranicza się do tych działów gospodarki, które są „społecznie pożądane”, lecz nie mogą być prowadzone przez przedsiębiorstwa prywatne (np. część usług zdrowotnych i sanitarnych, usługi komunalne, budowa dróg itd.) lub tych, które są nierentowne. W kwestii pomocy socjalnej państwa neoliberałowie uważają, że powinna mieć ona charakter ograniczony i obejmować jedynie te osoby, które znajdują się w krańcowo trudnej sytuacji. Pomoc ma mieć charakter jednostkowy, charytatywny i nie może 
prowadzić do redystrybucji dóbr materialnych między poszczególnymi grupami. Za najlepszą formę walki z ubóstwem zwolennicy neoliberalizmu uznają wzrost zamożności całego społeczeństwa, a taki jest możliwy tylko w warunkach wolnej konkurencji i nierówności ekonomicznej, która gwarantuje bodźce dla indywidualnej inicjatywy, przedsiębiorczości i pracowitości. Do naczelnych wartości politycznych neoliberalizmu zalicza się: wolność pojmowaną w sposób negatywny, tj. jako „brak przymusu”, sprawiedliwość komutatywną, opartą na założeniu, iż jedynym kryterium „sprawiedliwej” płacy, dochodów jednostki lub ceny jest ich wartość rynkowa (rezultat działania podaży i popytu) oraz praworządność urzeczywistnianą za pomocą specyficznie pojmowanego prawa, tj. abstrakcyjnych (ogólnych), znanych, pewnych i powszechnie obowiązujących (równych wobec wszystkich) reguł prawnych. Skrajną wersją neoliberalizmu jest libertarianizm (Antoszewski, Herbut 2002, s. 252-253).

Neoliberalizm wyklucza myślenie i działania w kategoriach „my”, wierząc, że potęga skumulowanych indywidualnych wyborów (niewidzialna ręka) jakoś tam ochroni wspólne dobro. Retoryka konsumentów opiera się na słowie „ja”, tymczasem społeczeństwo ma jeden język - „my”. Neoliberałowie zbudowali swoją teorię na koncepcji jednostki, definiowanej jako homo oeconomicus (Bartyzel 2004, s. 125), dążącej do maksymalizacji swojego kapitału ludzkiego (Potulicka, Rutkowiak 2010).

Współcześnie, zwłaszcza po kryzysie ekonomicznym zapoczątkowanym w USA w latach 2007-2008 (który przerodził się w światowy kryzys gospodarczy, a obecnie kryzys zadłużenia), niektórzy ekonomiści, np. przedstawiciele Międzynarodowego Funduszu Walutowego, twierdzą, że narastająca fala krytyki gospodarki wolnorynkowej doprowadzi do zmiany założeń neoliberalizmu (Ostry i in. 2016). W literaturze z zakresu ekonomii coraz częściej opisuje się obecnie jedną z wariacji liberalizmu, jaką jest ordoliberalizm, którego powstanie mogliśmy obserwować w latach 30. i 40. XX wieku w Niemczech, a jego rozwój w latach 6o. w Republice Federalnej Niemiec. Czołowy przedstawiciel ordoliberalizmu w Niemczech W. Eucken opracował koncepcję wolnokonkurencyjnego ładu gospodarczego, którego urzeczywistnienie zapewniałoby indywidualną wolność wszystkim podmiotom gospodarczym poprzez swobodę konkurowania na rynkach, a to ostatecznie prowadziłoby do efektywności w sensie ekonomicznym (Kamińska 2013, s. 231). Założenia ordoliberalizmu zostały w pewnym stopniu urzeczywistnione, kiedy Ludwig Erhard zasiadał na stanowisku ministra gospodarki (1949-1963), a następnie kanclerza RFN (1963-1966).

$\mathrm{W}$ ordoliberalizmie, $\mathrm{w}$ przeciwieństwie do neoliberalizmu, najważniejszy jest fundamentalizm rynkowy i minimalizowanie roli państwa w kształtowaniu ładu społeczno-gospodarczego, przy czym zapewnienie odpowiedniego kształtu ładu ma charakter pierwszoplanowy. Krótko mówiąc, neoliberalizm oznacza „wolność bez ładu”, a ordoliberalizm - „wolność w ramach ładu”.

Zmiana założeń neoliberalizmu może wynikać z faktu, na który w swojej publikacji pt. Resilient liberalism in Europe's political economy wskazują Vivien A. Schmidt i Mark Thatcher. Udowadniają oni, że to właśnie w odniesieniu do idei liberalnych 
i neoliberalnych możemy, a może nawet powinniśmy używać pojęcia resilience. Autorzy zastanawiają się bowiem nad niezwykłą popularnością idei neoliberalnych w gospodarkach państw europejskich, które to idee pomimo: naukowego podważenia zasad ich konstytuujących, ich zmasowanej krytyki w mediach i publikacjach naukowych, negatywnych konsekwencji kryzysów ekonomicznych wywołanych oddziaływaniem tychże idei, wyraźnej ich porażki w warstwie społecznej i politycznej, przetrwały „niekorzystne czasy” i istnieją nadal. Można powiedzieć nawet, odwołując się do pojęcia resilience definiowanego na gruncie psychologii rozwojowej, że dzięki procesom i mechanizmom, które sprzyjają adaptacyjnemu i dobremu funkcjonowaniu pomimo doświadczanych w przeszłości lub obecnie przeciwności losu, idee te umocniły się i stanowią dominujący paradygmat, wedle którego reformuje się współczesne gospodarki państwowe (Schmidt, Thatcher 2013, s. xvi). Jest to temat niezwykle ciekawy, który może być źródłem dalszej pogłębionej analizy. Celem jednak tego artykułu jest próba odniesienia koncepcji social resilience do możliwości przeciwstawienia się oddziaływaniu ideologii neoliberalnej we współczesnych państwach demokratycznych.

\section{Społeczny i pedagogiczny potencjał koncepcji social resilience}

Zastosowanie koncepcji social resilience we współczesnych państwach demokratycznych polegałoby na przeciwstawieniu się jednostek i społeczności neoliberalnej koncepcji społeczeństwa obywatelskiego, definiowanego w tej koncepcji jako: przestrzeń do indywidualnych wyborów i samostanowienia jednostek, jako sfera różnorodności, konfliktów i zaangażowania na rzecz współpracy z innymi, jako przestrzeń wolności pozostająca w formalnym stosunku względem państwa poprzez rozwiązania instytucjonalne i decyzje polityczne, które nie mają odzwierciedlać jakiejś określonej koncepcji dobra, lecz układają się równolegle do odmiennych celów indywidualnych (Pietrzyk-Reeves 2006, s. 21). Neoliberalna koncepcja społeczeństwa obywatelskiego zawiera w sobie formułę ograniczającą kolektywne zaangażowanie obywateli w działalność na rzecz ochrony wspólnego dobra, gdyż wszelkie przedsięwzięcia i akcje organizacji społecznych postrzegane są przez neoliberałów jako zagrożenie dla własności indywidualnej i ograniczają potencjalne pole korzyści materialnych jednostek. To zbytnie nastawienie na materializm i indywidualną korzyść prowadzi do wyniszczenia solidarności międzyludzkiej, wspólnotowości i tym samym powoduje załamanie się struktury społecznego wsparcia (Michałowska 2013, s. 104). Zatem social resilience oznaczałoby przeciwstawienie się obywateli niekorzystnym warunkom rozwoju, polegające na uruchomieniu takich procesów i mechanizmów, które doprowadzą do osiągnięcia rozwojowego w postaci nowego wymiaru/nowej wersji wspólnoty obywateli, która funkcjonuje dobrze pomimo doświadczanych przeciwności losu. Nie oznacza to zatem powrotu do poprzedniego stanu, ale taką modyfikację zachowania, która doprowadzi do zabezpieczenia pożądanego efektu, w postaci ochrony konkretnych 
wartości. Społeczeństwa mogą zatem podejmować działania w ramach akcji organizacji społecznych, które - jak podkreśla Ladislau Dowbor - „wyraźnie odniosły sukces, od bardzo ubogiej Kerali po bardzo bogatą Szwecję i Kanadę, okazało się, że ich wspólnym mianownikiem jest zorganizowane i wymagające społeczeństwo obywatelskie, zmuszające państwo do rozliczania się z tego, na co przeznacza się zasoby i stwarzające atmosferę wymuszającą na przedsiębiorcach prywatnych respektowanie interesów społecznych i ekologicznych regionu, w którym się osadzają. W tym znaczeniu organizacje społeczeństwa obywatelskiego są coraz bardziej nieodzowne" (Dowbor 2009, s. 189).

Jednym z najważniejszych założeń koncepcji social resilience jest to, że jest ona efektem aktywnego procesu odpowiedzi na zagrożenie. Grupy nie pozostaja pasywne, wykorzystując jedynie istniejące zasoby. Social resilence jest efektem kreatywnego procesu, w którym ludzie wyposażeni w różnorodne narzędzia, włącznie z zasobami kolektywnymi i nowym obrazem samych siebie, utrzymują swój dobrostan na niezmienionym poziomie pomimo zmian w sferze społecznej. Z jednej strony narzędzia te powstały w wyniku odziaływania określonych czynników, z drugiej strony ich powstanie i uruchomienie zagwarantował sam neoliberalizm (Hall, Lamont 2013, s. 14). Jest to zjawisko, które za Ann Swidler autorzy książki nazywają culture in action, czyli zmianą kultury w działaniu, w ramach którego nadawanie znaczenia wartościom odbywa się w wyniku codziennych interakcji i w ramach wspólnych wysiłków politycznych (Swidler 2013).

Przykładem na różne postrzeganie zagrożenia, jakim niewątpliwie jest neoliberalizm oraz różne sposoby reakcji na to zagrożenie, mogą być badania Marcosa Anceloviciego, który badał rozwój związków zawodowych we Francji w dobie neoliberalnej (Ancelovici 2013). Współczesne analizy koncentrują się na traktowaniu neoliberalizmu jako egzogenicznego wstrząsu o homogenicznym charakterze, tymczasem Ancelovici udowadnia, że organizacja doświadcza neoliberalizmu jako serii wydarzeń rozwijających się w czasie, które wymagają interpretacji, a te z kolei zależą od zbioru obaw doświadczanych przez każdego z uczestników zdarzenia z osobna. Z jego badań wynika, że związki zawodowe we Francji postrzegają neoliberalizm jako wyzwanie stojące przed organizacją, które przejawia się głównie w spadku liczby członków, a odpowiedź oraz działanie organizacji skierowane jest właśnie na zapobieganie temu zjawisku. Kiedy neoliberalizm jest doświadczany na poziomie realiów życiowych, to staje się oczywiste, że to, jak jest on postrzegany, zależy od kontekstu, a odpowiedź jest formułowana na podstawie dostępnych zasobów kulturowych oraz poprzednich doświadczeń. Ancelovici w swojej analizie dochodzi do wniosku, że odpowiedź na zagrożenie zależy od narracji, w jakiej prezentowane jest to zagrożenie, procesu „uczenia się” reakcji na to zagrożenie przez osoby je doświadczające oraz na instytucjonalizacji działań uruchamianych względem powstałego zagrożenia. Autor podkreśla, że organizacje o bardziej heterogenicznym składzie, posiadające liderów o większej organizacyjnej autonomii, konstruują bardziej resilient (rezylientną) odpowiedź na doświadczane zagrożenie (Ancelovici 2013, s. 371). 
Publikacja Hall i Lamont ma charakter pracy zbiorowej, w której poszczególni autorzy rozdziałów prezentują różne przykłady zastosowania koncepcji social resilience w różnych kontekstach kulturowych, społecznych i politycznych. Koncepcja social resilience opiera się na społecznej więzi, ale społeczeństwa funkcjonują nie tylko zależnie od wzajemnych zależności, lecz także w oparciu o „wyobrażenia zbiorowe”. Kolektywny charakter tych wyobrażeń, jak podaje Korzeniewska, „wynika $\mathrm{z}$ faktu, że funkcjonują one w symbolicznej przestrzeni danej społeczności, czyli określone obrazy, mity czy opowieści są znane i podzielane przez członków danej społeczności (Korzeniewska 2015, s. 35). Wyobrażenia te obejmują także narracje dotyczące przeszłości i przyszłości społeczności, definiują, kto może do niej należeć oraz jakie wartości ją konstytuują. Te wyobrażenia zbiorowe są promowane i popularyzowane przez organizacje społeczne, których działania wpisują się w politykę ekonomiczno-socjalną społeczności lokalnych poprzez zastosowanie w swoich działaniach koncepcji social resilience. Przykłady takich działań znajdują się w książce Hall i Lamont, zwłaszcza rozdziale 9. Autor tego rozdziału Gérard Bouchard przywołuje przykład Quebecku, który z powodzeniem wdrożył założenia ekonomii społecznej, dzięki nawiązywaniu licznych wspólnych inicjatyw pomiędzy przedsiębiorstwami i organizacjami quasi-publicznymi w procesie deliberacji. Polityka publiczna, prowadzona przez decydentów rządzących w Qubecku, pomogła podtrzymać ten model, zbudowany całkowicie na sieci złożonej z organizacji społecznych (Bouchard 2013, s. 276).

Podobny przykład wykorzystania wyobrażeń zbiorowych w koncepcji social resilience pochodzi z państw nordyckich, w których pomimo podejmowania neoliberalnych reform przez decydentów politycznych wyobrażenia zbiorowe narodów, które promują poczucie dzielenia z innymi społecznej odpowiedzialności, stanowiły wielkie wsparcie dla organizacji społecznych i wdrożenia przez nie idei social resilience (Hall, Lamont 2013, s. 17).

Social resilience nie ogranicza się jedynie do działalności organizacji społecznych, dotyczy także państw. Skuteczne utrzymanie well-being obywateli było możliwe w tych krajach, w których neoliberalnym inicjatywom towarzyszyły zwiększone wysiłki państwa, mające na celu wzrost zabezpieczenia społecznego: we Francji, w Brazylii, Taiwanie, Korei Południowej. Z perspektywy neoliberalnej takie działanie państwa może być nielogiczne, jeśli wziąć pod uwagę wzrost społecznych wydatków i rynkowe współzawodnictwo, to nie idzie ze sobą w parze, a jednak we wspomnianych krajach takie działania odniosły sukces (Evans, Sewell 2013, s. 61).

Podobnie w Kanadzie, w której wzrost wydatków społecznych powiązano z redystrybucją dóbr zależną od dochodu. Wzrost zabezpieczenia socjalnego, wspartego dodatkowo dostępem do dóbr podstawowych, takich jak edukacja czy ochrona zdrowia, zdaniem badaczy, skutecznie zabezpiecza odsunięte w czasie długotrwałe efekty neoliberalnych zmian widoczne w dorosłym życiu obywateli, zwłaszcza w stanie ich zdrowia oraz rozwoju personalnym (Keating i in. 2013). 
Opisana wyżej koncepcja social resilience oraz przykłady wykorzystania jej potencjału społecznego we współczesnych państwach demokratycznych mogą prowadzić do refleksji nad tkwiącym także w niej potencjalem pedagogicznym, a co za tym idzie, nad możliwością jego wykorzystania w obszarze edukacji, wsparcia i terapii. Koncepcja ta bowiem może odgrywać ważną rolę w myśleniu o przekształceniu środowiska na rzecz pomocy jednostkom, zwłaszcza dzieciom i młodzieży, w ich rozwoju psychospołecznym.

W Polsce dopiero w ostatnim dziesięcioleciu koncepcja resilience zaczęła powoli cieszyć się zainteresowaniem psychologów i pedagogów. Praktycy jednak koncentrują się zasadniczo wokół resilience odnoszącej się głównie do terapii dzieci i młodzieży oraz wsparcia dorosłych, np. academic resilience dzieci z rodzin o niższym statusie ekonomicznospołecznym; koncepcja resilience w resocjalizacji; resilience w radzeniu sobie z nieśmiałością u dzieci; idei rezylientnej rodziny, która pielęgnuje wzajemne relacje; wykorzystanie koncepcji resilience $\mathrm{w}$ programach mających na celu integrację dzieci z rozbitych domów $\mathrm{z}$ drugim rodzicem; propagowanie założeń resilience wśród żołnierzy borykających się z zespołem stresu pourazowego PTSD (Rutkowska 2015, s. 45).

Sama koncepcja resilience jest bardzo atrakcyjna dla badaczy edukacji, i jak podkreśla Smulczyk, „W pracy dydaktycznej i wychowawczej, a także profilaktycznej i terapeutycznej z dziećmi i młodzieżą, kluczowe okazują się działania mające na celu rozwijanie pozytywnych zasobów uczniów i ich rodzin. Dzięki temu młodzi ludzie stają się bardziej odporni na działanie czynników ryzyka, a w konsekwencji lepiej przygotowani do funkcjonowania w świecie realnych zagrożeń" (Smulczyk 2016a, s. 209). Takie zastosowania koncepcji resilience mają już miejsce na gruncie polskiej pedagogiki społecznej.

Brak jest natomiast badań oraz programów edukacyjnych wykorzystujących w Polsce koncepcję social resilience, która mogłaby pomóc w kształceniu światłych obywateli respektujących zasady pluralistycznej, moralnej demokracji, którzy dla zabezpieczenia wspólnego dobra (well-being) będą potrafili podjąć kolektywne działania, dając tym samym odpór negatywnym skutkom oddziaływania dominującej, także w Polsce, ideologii neoliberalnej.

Taki stan rzeczy jest spowodowany prawdopodobnie marginalizowaniem znaczenia postawy obywatelskiej w polskiej przestrzeni publicznej, opartej na altruizmie i bezinteresowności, co potwierdza w swoim artykule Szelewa, pisząc, że: „aktorzy tradycyjnie kojarzeni z progresywną polityką społeczną albo tracą w Polsce na ważności, albo od początku transformacji nie są w stanie przeciwstawić się dominującemu neoliberalnemu sposobowi myślenia. Co ważne, niezdolność pewnych aktorów do działania wynika z natury ideologii, którym chcą się przeciwstawić: jest to następstwem wzajemnie wzmacniającej się wielowątkowości neoliberalizmu" (Szelewa 2014, s. 25).

Dominująca obecnie ideologia neoliberalna zakłada określony scenariusz rozwoju osobistego ludzi, w oparciu o zasadę przystawalności i produktywności 
przyszłych obywateli, którzy mają traktować, planować i realizować swoje cele życiowe w kategoriach projektu biznesowego przynoszącego wymierne korzyści materialne. Rola edukacji w tym procesie została sprowadzona do tworzenia ekonomii

opartej na wiedzy, zwłaszcza poprzez system szkoleń zawodowych i nieustannego przekwalifikowywania się pracowników. Działania takie prowadzą do „wzrostu mobilności zawodowej, przemieszczania się z jednego miasta, kraju, kontynentu do drugiego i powoduje zaburzenie funkcjonowania społeczności lokalnej i małych wspólnot, a lojalność wobec pracodawcy maleje" (Michałowska 2013, s. 104). W konsekwencji prowadzi to do braku poczucia wspólnotowości, powoduje załamanie się struktury wsparcia społecznego i zburzenia solidarności międzyludzkiej.

Zatem potencjał pedagogiczny koncepcji social resilience mógłby być wykorzystany na gruncie edukacji, zwłaszcza w ramach kształcenia i wychowania przyszłych obywateli kraju, którzy powinni być przygotowani do aktywnego pełnienia ról obywatelskich i powinni posiadać umiejętności pozwalające im na włączenie się w różne formy życia społecznego. Koncepcja social resilience może być przykładem projektu przekształcania rzeczywistości na rzecz zmiany społecznej mentalności i stylu życia obywateli, co wpisuje się w zdefiniowane przez Rutkowiaka działania: „Działania oporowe i odporowe wobec kultury neoliberalnej w celu tworzenia wspólnoty współpracujących i prospołecznych ludzi oraz społeczeństwa obywatelskiego, nastawionego na obronę wartości publicznych" (Potulicka, Rutkowiak 2010, s. 306-307).

\section{Bibliografia}

Ancelovici M. (2013). The origins and dynamics of organizational resilience: a comparative study of two french labor organizations. W: Hall P. A., Lamont M. (red). Social resilience in the neoliberal era. New York: Cambridge University Press.

Antoszewski A., Herbut R. (2002). Leksykon politologii. Wrocław: Atla 2.

Bartyzel J. (2004). W gąszczu liberalizmów. Próba periodyzacji i klasyfikacji. Lublin: Fundacja „Servire Veritati”.

Borucka A., Ostaszewski K. (red). (2008). Koncepcja resilience. Kluczowe pojęcia i wybrane zagadnienia. „Medycyna Wieku Rozwojowego”, 12, s. 587-597.

Bouchard G. (2013). Neoliberalism in Québec: the response of a small nation under pressure. W: Hall P. A., Lamont M. (red). Social resilience in the neoliberal era. New York: Cambridge University Press.

Cottle S. (2009). Global crises in the news: staging new wars, disasters and climate change. „International Journal of Communication”, vol. 3, s. 494-516.

Dowbor L. (2009). Demokracja ekonomiczna. Warszawa: Książka i Prasa.

Evans P.B, Sewell W.H. (2013). Neoliberalism: policy regimes, international regimes, and social effects. W: Hall P. A., Lamont M. (red). Social resilience in the neoliberal era. New York: Cambridge University Press. 
Folke C. (2006). Resilience: the emergence of a perspective for social-ecological system analysis. „Global Environmental Change”, 16, s. 253-267.

Gąsior K. (2014). Prężność rodzinna - nowe wyzwanie dla profilaktyki. „Resocializacja Polska”, nr 6, s. 79-88.

Hall P. A., Lamont M. (red). (2013). Social resilience in the neoliberal era. New York: Cambridge University Press.

Junik W. (red). (2011). Resilience. Teoria-badania-praktyka. Warszawa: Parpamedia. Junik W. (2012). Koncepcja rezyliencji w praktyce andragogicznej. „Edukacja Ustawiczna Dorosłych", 1 (76), s. 76-83.

Kamińska K. (2013). Społeczna gospodarka rynkowa jako model ładu gospodarczego Unii Europejskiej. „Ekonomia”, 4 (25), s. 228-240.

Keating D., Siddiqi A., Nguyen Q. (2013). National differences in population health and development. W: Hall P. A., Lamont M. (red). Social resilience in the neoliberal era. New York: Cambridge University Press.

Korzeniewska A. (2015). Badania nad wyobrażeniami zbiorowymi dotyczacymi przeszłości po II wojnie światowej wobec przemian kulturowych i społeczych. "Sensus Historiae”, vol. XVIII, s. 35-52.

Masten A., Narayan A. J. (2012). Child development in the context of disaster, war and terrorism: pathways of risk and resilience. "Annual Review of Psychology”, vol. 63, s. 227-257.

Michałowska D. A. (2013). Neoliberalizm i jego (nie)etyczne implikacje edukacyjne. Poznań: Wydawnictwo Naukowe UAM.

Ostry J. D., Loungani P., Furceri D. (2016). Neoliberalism: Oversold? „Finances and Development”, vol. 53, nr 2, dostępny na http://www.imf.org/external/pubs/ft/ fandd/2016/o6/ostry.htm (otwarto: 8.03.2018).

Pietrzyk-Reeves D. (2006). Współczesny kształt idei społeczeństwa obywatelskiego. W: Krauz- Mozer B., Borowiec P. (red). Czas społeczeństwa obywatelskiego, między teoria a praktyką. Kraków: Wydawnictwo Uniwersytetu Jagiellońskiego.

Potulicka E., Rutkowiak J. (2010). Neoliberalne uwikłania edukacji. Kraków: Oficyna Wydawnicza „Impuls”.

Rutkowska M. (2015). Rezyliencja jako interdyscyplinarna kategoria analityczna i jej zastosowanie w pedagogice. "Studia i Badania Naukowe”, 1, s. 29-47.

Sinha S. (2009). Projekt neoliberalny a możliwości społeczeństwa obywatelskiego. W: Saad-Filho A., Johnston D. (red). Neoliberalizm przed trybunałem. Warszawa: Książka i Prasa.

Schmidt V. A., Thatcher M. (red.) (2013). Resilient liberalism in Europe's political economy. London: Cambridge University Press

Smulczyk M. (2016a). Resilience a edukacja. Rola fenomenu skutecznej adaptacji w osiagnięciach szkolnych. „Forum Oświatowe”, 28 (2), s. 203-222.

Smulczyk M. (2016b). Problematyka academic resilience-teoria, badania, praktyczne zastosowanie. „Przegląd Badań Edukacyjnych”, 23, s. 165-194. 
Swidler A. (2013). Cultural Sources of Institutional resilience: lessons from chieftaincy in rural Malawi. W: Hall P. A., Lamont M. (red). Social resilience in the neoliberal era. New York: Cambridge University Press.

Szelewa D. (2014). Procesy polityczne a strategia zmian polityki społecznej w Polsce i na świecie, „Warszawskie Debaty o Polityce Społecznej”, dostępny na: http:// library.fes.de/pdf-files/bueros/warschau/11373.pdf (otwarto: 20.08.2017).

\title{
THE SOCIAL AND PEDAGOGICAL POTENTIAL OF THE SOCIAL RESILIENCE CONCEPT IN THE NEOLIBERAL ERA
}

\begin{abstract}
In the article I would like to present the social and pedagogical potential of the concept of social resilience, which can be an effective way to maintain the well-being by individuals and communities, especially in the face of threats caused by the impact of neoliberal ideology. In a comprehensive way, I will present definitions of terms used in the article such as: resilience, social resilience, neoliberal ideology. I will try to give examples of using the social potential of the social resilience concept, which are currently successfully operating in modern democratic countries. I will also present examples of the current application of the resilience concept on the basis of Polish psychology and pedagogy and I will show the possibilities of extending this concept with a social factor and using its pedagogical potential in the field of education.
\end{abstract}

Key words: resilience, social resilience, neoliberalism.

Celina Czech-Włodarczyk - adiunkt w Zakładzie Pedagogiki Porównawczej na Wydziale Studiów Edukacyjnych Uniwersytetu im. Adama Mickiewicza w Poznaniu; absolwentka pedagogiki specjalnej w zakresie rehabilitacji i edukacji dzieci niepełnosprawnych intelektualnie; absolwentka politologii w zakresie administracji europejskiej. Zainteresowania badawcze: funkcjonowanie i reformowanie systemów edukacyjnych w Ameryce Północnej, zwłaszcza w Kanadzie, oraz systemów w Europie, szczególnie we Francji i Wielkiej Brytanii; innowacje w zakresie metod nauczania dzieci o specjalnych potrzebach edukacyjnych; edukacja mniejszości narodowych, etnicznych i językowych na terenie Kanady i Francji; globalizacja i jej oddziaływanie na sferę edukacji; wpływ czynników ekonomicznych i ideologicznych na reformy podejmowane w sferze edukacji. Adres do korespondencji: Szamarzewskiego 89, bud. D, pok. 415-416, 60-568 Poznań. Adres e-mailowy: cczech@ amu.edu.pl. 